\title{
Growth, Yield Attributes and Yield of Pigeonpea + Niger Intercropping System as Influenced by Planting Pattern under Rainfed Condition of Marathwada Region
}

\author{
Y. Lavanya ${ }^{1 *}$ and N.G. Kurhade ${ }^{2}$ \\ ${ }^{1}$ Department of Agronomy, TNAU, Coimbatore-641003, Tamil Nadu, India \\ ${ }^{2}$ Department of Agronomy, VNMKV, Parbhani-431402, Maharashtra, India \\ *Corresponding author
}

\begin{abstract}
A B S T R A C T

\begin{tabular}{|l|}
\hline Ke y w or d s \\
Pigeonpea, Niger, \\
$\begin{array}{l}\text { Intercropping system, } \\
\text { Planting pattern }\end{array}$ \\
\hline Article Info \\
\hline $\begin{array}{l}\text { Accepted: } \\
18 \text { October } 2018 \\
\text { Available Online: } \\
10 \text { November } 2018\end{array}$ \\
\hline
\end{tabular}
\end{abstract}

\section{Introduction}

Pigeonpea [Cajanus cajan (L.) Millsp.] This is also well known as redgram, arhar, tur, congopea, gungopea, no eye pea. It is an important kharif pulse crop grown for its dhal, fuel, and fodder belonging to the family fabaceae. It provides protein rich food, firewood and income for resource poor small farmers. With the complementary effect of pigeonpea on soil fertility improvement, nutrient recycling, smothering of weeds and efficient utilization of soil moisture under different cropping systems, it occupies more area in cropping systems than as a sole crop. Niger (Guizotiaabyssinica) commonly known as ramtil, kalatiland gurelluis a minor oilseed crop of India belongs to the family compositeae, indigenous to tropical Africa particularly to Ethiopia islands. It is very important oilseed crop in terms of oil content (40 percent), quality and potentiality. In India during 2016-17 pigeonpea was cultivated an area of 5.39 m.ha with a production of 4.60 m.t and productivity of $854 \mathrm{~kg} \mathrm{ha} \mathrm{h}^{-1}$ andniger was cultivated an area of $2.51 \mathrm{~m}$.ha with a production of $0.74 \mathrm{~m} . t$ and productivity of 295 $\mathrm{kg} \quad \mathrm{ha}^{-1}$.In Maharashtraduring 2016-17 
pigeonpea was cultivated an area of 1.26 m.ha with a production of 0.93 m.t and productivity of $741 \mathrm{~kg} \mathrm{ha}^{-1}$ andniger was cultivated an area of 0.17 m.ha with a production of 0.04 m.t and productivity of $235 \mathrm{~kg} \mathrm{ha}^{-1}$. (Ministry of Agriculture and farmers welfare, GOI 2017). Among the abiotic constraints, the methods of planting and plant population play an important role in production of grain yield of pigeonpea. Thus it becomes necessary to develop an efficient and profitable pigeonpea based intercropping system for scarcity zone of Maharashtra. Success of any crop depends on use of quality seed and improved cultural practices. Among the agronomic practices, spacing play important role in maximizing the grain yield. A few studies of intercropping pigeonpea with oilseed like soybean, groundnut, sunflower etc., with pulses like green gram, black gram etc., was success. But studies on pigeonpea + niger intercropping system was lacking in India. An account of these facts an experiment was undertaken pigeonpea + niger intercropping system in different row proportion.

\section{Materials and Methods}

The experiment was conducted during kharif 2016 in Research farm of Division of Agronomy, Vasantrao Naik Marathwada Krishi Vidyapeeth, Parbhani. Geographically location of the site is situated at $19^{0} 16^{\prime}$ North latitude and $76^{\circ} 47^{\prime}$ East longitude and at 409 altitudes above sea level and has a semi-arid climate. The mean annual rainfall received during the crop growing period was $1127 \mathrm{~mm}$. The experimental soil was black soil having $\mathrm{pH}$ 8.1, medium in organic carbon $(0.56 \%)$, low in available nitrogen $\left(215.03 \mathrm{kgha}^{-1}\right)$ medium in available phosphorus $\left(14.96 \mathrm{kgha}^{-}\right.$ $\left.{ }^{1}\right)$ medium in available $\mathrm{K}\left(506.6 \mathrm{kgha}^{-1}\right)$. The experiment was laid out in RBD with 3 replications consists of 8 treatment combinations viz., $\mathrm{T}_{1}$ - pigeonpea + niger $(1: 2$; $90 \times 30 \mathrm{~cm}), \mathrm{T}_{2}-$ pigeonpea + niger $(1: 2 ; 90 \times 30$ $\mathrm{cm}), \mathrm{T}_{3}$ - pigeonpea + niger $(1: 3 ; 120 \times 30 \mathrm{~cm})$, $\mathrm{T}_{4^{-}}$pigeonpea + niger $(1: 3 ; 120 \times 45 \mathrm{~cm}), \mathrm{T}_{5^{-}}$ pigeonpea + niger $(1: 4 ; 150 \times 30 \mathrm{~cm}), \mathrm{T}_{6^{-}}$ pigeonpea + niger $(1: 4 ; 150 \times 45 \mathrm{~cm}), \mathrm{T}_{7}$ - sole pigeonpea $(90 \times 20 \mathrm{~cm}), \mathrm{T}_{8}$-sole niger $(30 \times 10$ $\mathrm{cm})$. The recommended dose of fertilizer for pigeonpea and Niger was applied separately

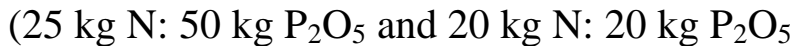
respectively).

The herbicide Pendimethalin@ 1.0 kg a.i. ha ${ }^{-1}$ was sprayed as pre-emergence for controlling weed and followed by hand weeding. Other package of practices was followed as per recommendation of Maharashtra state Department of Agriculture 2016. The plants from net plot were harvested from the ground level and were left for sun drying in the same field and were threshed manually. Grains were cleaned and weighed for expressing yields in $\mathrm{kgha}^{-1}$. The weight of stalks was recorded separately and used for estimating stover yield. Pigeonpea equivalent yield was worked out for yield of one crop converted in to equivalent yield of other component crop using the following formula PEY (kg/ha).

\section{Results and Discussion}

\section{Growth characters: Plant height}

Sole crop of pigeonpea $(90 \times 20 \mathrm{~cm})$ had significant influence on plant height (148.7 $\mathrm{cm}$ ) due to more availability of all resources like nutrient, moisture and space. Sole crop of pigeonpea treatment was on par with pigeonpea intercropped with niger in 1:4 ratio and 1:2 ratio due to more competition of nutrients and light. Pigeonpea intercropped with niger in 1:3 ratio had recorded lower plant height of pigeonpea due to adequate space and proper row proportion. This result was in accordance withYadav and Maurya (2012) who reported that closely spaced pigeonpea plants grow rapidly in pigeonpea + soybean intercropping system (Table 1). 


\section{Int.J.Curr.Microbiol.App.Sci (2018) 7(11): 2303-2309}

Table.1 Growth parameters of pigeonpea + niger intercropping system as influenced by planting pattern at harvest

\begin{tabular}{|c|c|c|c|c|c|c|c|c|c|c|c|}
\hline \multirow[t]{3}{*}{ Treatment } & \multicolumn{2}{|c|}{$\begin{array}{l}\text { Plant height } \\
\text { (cmplant }^{-1)}\end{array}$} & \multicolumn{2}{|c|}{$\begin{array}{l}\text { No. of functional } \\
\text { leaves }\end{array}$} & \multicolumn{3}{|c|}{ No. of branches } & \multicolumn{2}{|c|}{$\begin{array}{c}\text { Leaf area }\left(\mathrm{dm}^{2}\right. \\
\left.\text { plant }^{-1}\right)\end{array}$} & \multicolumn{2}{|c|}{$\begin{array}{l}\text { Drymatter } \\
\text { production } \\
\left(\text { g plant }^{-1}\right)\end{array}$} \\
\hline & \multirow{2}{*}{$\begin{array}{l}\text { Main } \\
\text { crop }\end{array}$} & \multirow[t]{2}{*}{ Inter crop } & \multirow{2}{*}{$\begin{array}{l}\text { Main } \\
\text { crop }\end{array}$} & \multirow{2}{*}{$\begin{array}{l}\text { Inter } \\
\text { crop }\end{array}$} & \multirow{2}{*}{$\begin{array}{l}\text { Main } \\
\text { crop }\end{array}$} & \multicolumn{2}{|c|}{ Inter crop } & \multirow{2}{*}{$\begin{array}{l}\text { Main } \\
\text { crop }\end{array}$} & \multirow[t]{2}{*}{ Inter crop } & \multirow[t]{2}{*}{ Main crop } & \multirow{2}{*}{$\begin{array}{l}\text { Inter } \\
\text { crop }\end{array}$} \\
\hline & & & & & & primary & secondary & & & & \\
\hline $\begin{array}{c}1: 2 \\
(90 \times 30 \mathrm{~cm}: 30 \times 10 \mathrm{~cm})\end{array}$ & 142.1 & 91.3 & 112.9 & 42.1 & 11.5 & 9.2 & 12.4 & 76.4 & 26.32 & 106.4 & 27.5 \\
\hline $\begin{array}{c}1: 2 \\
(90 \times 45 \mathrm{~cm}: 30 \times 10 \mathrm{~cm})\end{array}$ & 135.8 & 90.2 & 118.8 & 44.5 & 11.7 & 9.6 & 12.6 & 88.4 & 26.33 & 106.6 & 27.9 \\
\hline $\begin{array}{c}1: 3 \\
(120 \times 30 \mathrm{~cm}: 30 \times 10 \mathrm{~cm})\end{array}$ & 117.5 & 96.0 & 184.0 & 38.4 & 12.9 & 8.6 & 11.6 & 92.1 & 24.67 & 109.9 & 26.0 \\
\hline $\begin{array}{c}1: 3 \\
(120 \times 45 \mathrm{~cm}: 30 \times 10 \mathrm{~cm})\end{array}$ & 113.6 & 95.6 & 188.0 & 40.8 & 13.2 & 8.8 & 11.8 & 97.6 & 24.68 & 112.0 & 26.9 \\
\hline $\begin{array}{c}1: 4 \\
(150 \times 30 \mathrm{~cm}: 30 \times 10 \mathrm{~cm})\end{array}$ & 133.5 & 103.8 & 140.0 & 34.6 & 11.8 & 7.7 & 10.5 & 90.9 & 23.03 & 108.1 & 24.2 \\
\hline $\begin{array}{c}1: 4 \\
(150 \times 45 \mathrm{~cm}: 30 \times 10 \mathrm{~cm})\end{array}$ & 132.2 & 100.4 & 143.8 & 36.5 & 12.3 & 8.1 & 10.7 & 91.0 & 23.54 & 108.4 & 24.9 \\
\hline $\begin{array}{l}\text { Sole pigeonpea } \\
(90 \times 20 \mathrm{~cm})\end{array}$ & 148.7 & 0.0 & 217.0 & 0.0 & 14.8 & 0.0 & 0.0 & 105.9 & 0.0 & 120.0 & 0.0 \\
\hline $\begin{array}{l}\text { Sole niger } \\
(30 \times 10 \mathrm{~cm})\end{array}$ & 0.0 & 107.2 & 0.0 & 32.8 & 0.0 & 7.4 & 9.5 & 0.0 & 21.66 & 0.0 & 23.6 \\
\hline $\mathrm{SE}_{\mathrm{m}} \pm$ & 5.9 & 3.2 & 11.8 & 2.2 & 0.67 & 0.3 & 0.46 & 4.62 & 0.76 & 3.3 & 0.8 \\
\hline $\mathrm{CD}$ & 17.8 & 9.8 & 35.6 & 6.8 & 2.03 & 0.9 & 1.42 & 14.00 & 2.31 & 10.1 & 2.5 \\
\hline
\end{tabular}




\section{Int.J.Curr.Microbiol.App.Sci (2018) 7(11): 2303-2309}

Table.2 Effect of planting pattern in pigeonpea + niger intercropping on yield attributes at harvest

\begin{tabular}{|c|c|c|c|c|c|c|c|c|}
\hline \multirow[t]{2}{*}{ Treatment } & \multicolumn{4}{|c|}{ Pigeonpea (main crop) } & \multicolumn{4}{|c|}{ Niger (inter crop) } \\
\hline & $\begin{array}{l}\text { No. of } \\
\text { pods plant }\end{array}$ & $\begin{array}{l}\text { Wt. of } \\
\text { pods (g } \\
\left.\text { plant }^{-1}\right)\end{array}$ & $\begin{array}{l}\text { Wt. of } \\
\text { seeds }(g \\
\left.\text { plant }^{-1}\right)\end{array}$ & $\begin{array}{l}\text { Seed } \\
\text { Index } \\
(\mathrm{g})\end{array}$ & $\begin{array}{l}\text { No. of } \\
\text { capitulae } \\
\text { plant }^{-1}\end{array}$ & $\begin{array}{l}\text { Wt. of } \\
\text { capitulae }(g \\
\left.\text { plant }^{-1}\right)\end{array}$ & $\begin{array}{l}\text { Wt. of } \\
\text { seeds }(g \\
\left.\text { plant }^{-1}\right)\end{array}$ & $\begin{array}{l}\text { Test } \\
\text { weight } \\
(\mathrm{g})\end{array}$ \\
\hline $\begin{array}{c}1: 2 \\
(90 \times 30 \mathrm{~cm}: 30 \times 10 \mathrm{~cm})\end{array}$ & 105.0 & 61.65 & 30.15 & 8.6 & 43.7 & 5.59 & 4.7 & 4.80 \\
\hline $\begin{array}{c}1: 2 \\
(90 \times 45 \mathrm{~cm}: 30 \times 10 \mathrm{~cm})\end{array}$ & 112.5 & 63.03 & 31.53 & 8.7 & 44.0 & 5.64 & 4.8 & 4.82 \\
\hline $\begin{array}{c}1: 3 \\
(120 \times 30 \mathrm{~cm}: 30 \times 10 \mathrm{~cm})\end{array}$ & 121.8 & 75.04 & 41.54 & 10.4 & 41.7 & 5.42 & 4.4 & 4.73 \\
\hline $\begin{array}{c}1: 3 \\
(120 \times 45 \mathrm{~cm}: 30 \times 10 \mathrm{~cm})\end{array}$ & 128.0 & 77.55 & 44.05 & 10.6 & 42.2 & 5.53 & 4.5 & 4.76 \\
\hline $\begin{array}{c}1: 4 \\
(150 \times 30 \mathrm{~cm}: 30 \times 10 \mathrm{~cm})\end{array}$ & 114.7 & 67.86 & 35.36 & 9.4 & 37.8 & 5.37 & 4.2 & 4.60 \\
\hline $\begin{array}{c}1: 4 \\
(150 \times 45 \mathrm{~cm}: 30 \times 10 \mathrm{~cm})\end{array}$ & 117.5 & 69.11 & 36.61 & 9.5 & 38.2 & 5.38 & 4.2 & 4.65 \\
\hline $\begin{array}{l}\text { Sole pigeonpea } \\
(90 \times 20 \mathrm{~cm})\end{array}$ & 134.0 & 83.08 & 49.58 & 11.4 & 0.0 & 0.0 & 0.0 & 0.0 \\
\hline $\begin{array}{l}\text { Sole niger } \\
(30 \times 10 \mathrm{~cm})\end{array}$ & 0.0 & 0.0 & 0.0 & 0.0 & 29.8 & 4.66 & 3.6 & 4.20 \\
\hline $\mathrm{SE}_{\mathrm{m}} \pm$ & 3.9 & 2.7 & 2.98 & 0.4 & 1.38 & 0.07 & 0.20 & 0.23 \\
\hline CD & 12.0 & 8.2 & 9.04 & 1.4 & 4.19 & 0.24 & 0.56 & NS \\
\hline
\end{tabular}




\section{Int.J.Curr.Microbiol.App.Sci (2018) 7(11): 2303-2309}

Table.3 Effect of planting pattern on yield of pigeonpea + niger intercropping at harvest

\begin{tabular}{|c|c|c|c|c|c|c|c|}
\hline \multirow{2}{*}{ Treatment } & \multicolumn{2}{|c|}{ Seed yield $\left(\mathrm{kgha}^{-1}\right)$} & \multirow{2}{*}{$\begin{array}{c}\text { Pigeonpea } \\
\text { equivalent yield } \\
\left(\mathrm{kgha}^{-1}\right)\end{array}$} & \multicolumn{2}{|c|}{ Stalk yield $\left(\mathrm{kgha}^{-1}\right)$} & \multicolumn{2}{|c|}{ Harvest index } \\
\hline & Main crop & Inter crop & & Main crop & Inter crop & Main crop & Inter crop \\
\hline $\begin{array}{c}1: 2 \\
(90 \times 30 \mathrm{~cm}: 30 \times 10 \mathrm{~cm})\end{array}$ & 1070.74 & 699.8 & 1311.81 & 3725.26 & 3398.82 & 22.35 & 17.07 \\
\hline $\begin{array}{c}1: 2 \\
(90 \times 45 \mathrm{~cm}: 30 \times 10 \mathrm{~cm})\end{array}$ & 734.56 & 703.4 & 1077.77 & 2968.43 & 3451.08 & 19.83 & 16.93 \\
\hline $\begin{array}{c}1: 3 \\
(120 \times 30 \mathrm{~cm}: 30 \times 10 \mathrm{~cm})\end{array}$ & 1022.77 & 760.8 & 1384.05 & 3213.24 & 3796.70 & 24.14 & 16.69 \\
\hline $\begin{array}{c}1: 3 \\
(120 \times 45 \mathrm{~cm}: 30 \times 10 \mathrm{~cm})\end{array}$ & 718.66 & 762.5 & 1127.64 & $2617 . .35$ & 3828.62 & 21.54 & 16.60 \\
\hline $\begin{array}{c}1: 4 \\
(150 \times 30 \mathrm{~cm}: 30 \times 10 \mathrm{~cm})\end{array}$ & 722.80 & 790.0 & 1321.16 & 2871.2 & 3882.65 & 20.11 & 16.90 \\
\hline $\begin{array}{c}1: 4 \\
(150 \times 45 \mathrm{~cm}: 30 \times 10 \mathrm{~cm})\end{array}$ & 494.14 & 795.2 & 981.99 & 2382.85 & 3901.32 & 17.15 & 16.93 \\
\hline $\begin{array}{l}\text { Sole pigeonpea } \\
(90 \times 20 \mathrm{~cm})\end{array}$ & 1650 & 0.0 & 1650 & 5165 & 0.0 & 24.21 & 0.0 \\
\hline $\begin{array}{l}\text { Sole niger } \\
(30 \times 10 \mathrm{~cm})\end{array}$ & 0.0 & 853.9 & 646.76 & 0.0 & 4652.66 & 0.0 & 15.50 \\
\hline $\mathrm{SE}_{\mathrm{m}} \pm$ & 24.96 & 23.0 & 188 & 318.9 & 261.5 & 0 & 0 \\
\hline CD & 95.64 & 72.1 & 564 & 966.2 & 792.6 & 0 & 0 \\
\hline
\end{tabular}


The plant height of sole niger crop recorded significantly superior and which was on par with row proportion of 1:4 because more plant population due to competition with main crop and inter crops. The row proportion of 1:4 ratios was on par with all the remaining treatments. The lower plant height of niger was recorded in 1:2 row proportion. Similar concomitant findings were observed in Sonawane et al., (2011) also reported that closely spaced soybean plants grow rapidly.

\section{No. of functional leaves, branches, leaf area and dry matter production}

Sole pigeonpea $(90 \times 20 \mathrm{~cm})$ had also significantly influenced on maximum no, of functional leaves, branches, leaf area) and dry matter production $\left(217,14.8,105.9 \mathrm{dm}^{2}, 120\right.$ $\mathrm{g}_{\text {plant }}{ }^{-1}$ respectively) due to less competition between plant to plant compared to other treatments. It was on par with 1: 3 row proportion of pigeonpea + niger intercropping system than other row proportion, because more aggressivity behaviour of pigeonpea on niger than other row proportion.

In niger maximum no. of leaves, branches, leaf area, dry matter production (44.5, primary-9.6, secondary-12.6, 26.33 $\mathrm{dm}^{2}, 27.9$ g plant ${ }^{-1}$ respectively) was recorded under planting geometry $(1: 2 ; 90 \times 45 \mathrm{~cm})$. This might be due to less competition for nearer rows of Niger to soil moisture and space for leaf proliferation and less aggressive behaviour of pigeonpea on Niger. It was on par with planting geometry $(1: 2 ; 90 \times 30 \mathrm{~cm})$ and 1:3 rows proportion. The lower no. of leaves, branches, leaf area and dry matter production of niger was recorded under sole niger $(30 \times 10 \mathrm{~cm})$

\section{Yield and yield attributes}

In pigeonpea no. of pods, weight of pods, weight of seeds, seed index $(134,83.8 \mathrm{~g}$,
$49.58 \mathrm{~g}, 11.4 \mathrm{~g}$ plant $^{-1}$ respectively) were significantly higher under sole pigeonpea $(90 \times 20 \mathrm{~cm})$. This was followed by $1: 3$ rows proportion over other planting geometry in different row proportion. This might be due to lower production of photosynthates and more competition for space, nutrients, and soil moisture due to reduced nutritional area plant $^{-1}$. These results are in conformity with the research findings concluded by Ujjinath et al., (1990) (Table 2).

Planting geometry of Niger crop (1:2; $90 \times 45 \mathrm{~cm})$ was recorded maximum no. of capitulae, weight of capitulae, weight of seeds (44, 5.64 g 4.8 g plant $^{-1}$ respectively), which was on par with planting geometry $(1: 2$; $90 \times 30 \mathrm{~cm})$ and $1: 3$ rows proportion due to maximum no. of leaves results to higher production of photosynthates.

Higher pigeonpea equivalent yield $(1650 \mathrm{~kg}$ $\mathrm{ha}^{-1}$ ) was obtained in narrow planting geometry of sole pigeonpea $(90 \times 20 \mathrm{~cm})$ due to higher seed yield. The similar trends of results are found in pigeonpea based intercropping system by Rathod et al., (1990). The lower pigeonpea equivalent yield (981.99 $\mathrm{kg} \mathrm{ha}^{-1}$ ) was recorded in wider planting geometry of pigeonpea + niger $(1: 4 ; 150 \times 45 \mathrm{~cm})$ in intercropping system. This could be attributed to lesser aggressivity of pigeonpea + niger intercropping system (Table 3).

From findings it can be concluded that Pigeonpea equivalent yield ( $\mathrm{kg} / \mathrm{ha})$ was significantly higher in sole pigeonpea $(90 \times 20 \mathrm{~cm})$ followed by pigeonpea $(120 \times 30 \mathrm{~cm})+$ niger in $1: 3$ row proportion pigeonpea $(150 \times 30 \mathrm{~cm})+$ niger in $1: 4$ row proportion and pigeonpea $(90 \times 30 \mathrm{~cm})+$ niger in 1:2 row proportion $\left(1650 \mathrm{kgha}^{-1}, 1384.05\right.$ $\mathrm{kgha}^{-1}, \quad 1321.6 \mathrm{kgha}^{-1}$ and $1311.81 \mathrm{kgha}^{-1}$ respectively). Lower pigeonpea equivalent yield was recorded in sole niger with planting geometry of 30x10 cm $\left(646.76 \mathrm{kgha}^{-1}\right)$. 


\section{References}

Chaudhary, S.K. and S.K. Thakur. 2005. Productivity of pigeonpea (Cajanus cajan) based inter crops. Indian J.Agri.Sci., 75(8): 496-497.

Darshan, R. 2008. Intercropping of pigeonpea with sesame cultivars under different planting geometry and row proportions in northern transition zone of Karnataka. M.sc (agri) thesis, Uni.Agri.sci., Dharwad (India).

Das, S.R., P.K. Mahpatra, D. Satpathy and S.K. Uttarya. 1991. Studies on pigeonpea + groundnut intercropping system. Indian J. Agron., 36(1): 129131.

Padhi, A.K., B.K. Sahod and K.C. Das. 1992. Productivity of rainfed pigeonpea (Cajanus cajan) based intercropping system. Indian J.Agri.Sci., 62(9): 594598.

Patil, P.A. and P.K. Joshi. 2002. Effect of planting pattern in Pigeonpea and Soybean intercropping. J. of Maharashtra Agric. Univ., 27(3): 268270.
Rathod, P.S., S.I. Halikatti, S.M. Hiremath and S.T. Kajjidoni. 2004a. Influence of different intercrops and row proportions on yield and yield parameters of pigeonpea in Vertisols of Dharwad. Karnataka J. Agric. Sci., 17: 652-657.

Sonawane, D.A., T.M. Bahale and N.D. Dalavi. 2011. Evaluation of pigeonpea based intercropping systems under scarcity condition of Northern Maharashtra. JNKVVRes. J., 45(1): 8184.

Ujjinath, U.S., B.R. Rajashekar, N. Venugopal and K. Senoappa. 1991. Sunflower scheme, University of Agriculture Sciences, GKVK, Bangalore-560065. J. Oilseeds Res., 8: 72-78. ISSNo.970-2776.

Yadav, P.S. and B.M. Maurya. 2012. Assessment of productivity and economics of various soybean + pigeonpea intercropping system under rainfed condition of Rewa region of Madhya Pradesh. JNKVVRes. J., 46(3): 355-359.

\section{How to cite this article:}

Lavanya, Y. and Kurhade, N.G. 2018. Growth, Yield Attributes and Yield of Pigeonpea + Niger Intercropping System as Influenced by Planting Pattern under Rainfed Condition of Marathwada Region. Int.J.Curr.Microbiol.App.Sci. 7(11): 2303-2309. doi: https://doi.org/10.20546/ijcmas.2018.711.259 